\title{
Entrepreneurial tendencies in franchising: evidence from the UK
}

\author{
Olufunmilola (Lola) Dada \\ Institute for Entrepreneurship and Enterprise Development; Lancaster University Management \\ School; Lancaster; UK. \\ Anna Watson \\ Hertfordshire Business School, University of Hertfordshire, UK \\ David A. Kirby \\ Faculty of Business Administration, Economics and Political Science; the British University in \\ Egypt; El Sherouk City; Egypt.
}

\section{Acknowledgments:}

The first author gratefully acknowledges the support of the Economic and Social Research Council (ESRC) in the UK, Grant number PTA-026-27-1853, in the preparation of this paper. Earlier versions of this paper have been presented at the 2006 and 2009 International Society of Franchising Annual Conference (ISoF), and the 2008 Institute for Small Business and Entrepreneurship Annual Conference (ISBE). We are grateful to the anonymous reviewers for their comments. Highlights from this study were featured in Franchise World (2009). 


\title{
Entrepreneurial tendencies in franchising: evidence from the UK
}

\begin{abstract}
Purpose - In spite of the important contributions of franchising to many economies, it remains unclear whether it truly provides a scope for entrepreneurial tendencies to flourish amongst franchisees. This study examines the debate surrounding the franchisee as an entrepreneur from the perspectives of the main contributors within the UK franchising sector, franchisors and franchisees, by analysing their entrepreneurial tendencies and the franchisee selection process.

Design/methodology/approach - The paper is based on an empirical study using a focus group and a survey approach.

Findings - The findings from this study demonstrate that franchisees have similar levels of entrepreneurial tendencies to franchisors. The results further indicate that franchisors appear to value entrepreneurial personalities within their franchised outlets, as demonstrated by their franchisee selection process.

Originality/value - By providing an indication of the extent of the franchisee's entrepreneurial tendencies, this study expatiates on major arguments in the franchising and entrepreneurship literature, which are also profound amongst practitioners in the fields of franchising and entrepreneurship.
\end{abstract}

Keywords Entrepreneurial personality characteristics, Franchising, Franchisee selection

Paper type Research paper 


\section{Introduction}

Franchising has become a significant form of business ownership in many economies. In the United States, where it is believed to have been pioneered, there are 909,253 franchised business establishments, resulting in 21 million jobs and $\$ 2.31$ trillion of annual output (PricewaterhouseCoopers, 2008). Such noteworthy trends are progressively being observed in many countries around the world. Despite the role franchising has played in global wealth creation (Hoy et al., 2000; Sorenson and Sørensen, 2001), a long-standing controversial issue in the academic literature, and even amongst practitioners, pertains to whether entrepreneurial personalities can thrive within franchised outlets. Most of these arguments have centred on the premise on which franchising is built, replicating uniform operations throughout the franchise system (Dada and Watson, 2013).

This article focuses on business format franchising, which "occurs when a firm (the franchisor) sells the right to use its trade name, operating systems, and product specifications to another firm (the franchisee)” (Castrogiovanni et al., 2006a, p. 27-28). Although prior franchising studies seldom viewed franchising as a form of entrepreneurship, recent franchising studies have adopted an approach that comes closer to entrepreneurship (Tuunanen, 2007; Tuunanen and Hoy, 2007). While contemporary research has now generally positioned the franchisor as an entrepreneur, the same cannot be said for their franchisees (see, for example, Ketchen et al., 2011), the implementators of the franchise concept (Spinelli et al., 2004). As franchising "does not afford the same degree of operational independence inherent within fully independent business enterprises” (Weaven et al., 2009, p. 93), franchisees are often depicted as not being 'real' entrepreneurs (Anderson et al., 1992), but 'controlled self-employed' (Felstead, 1991). The arguments surrounding the role of franchisees as the antithesis of entrepreneurs (Clarkin and Rosa, 2005) are well summarised in a recent article by Hoy (2008, p. 152) who noted that: "The owner of a franchise follows a model devised by others rather than engaging in innovative behaviour. Further, that owner sacrifices the independence associated with entrepreneurship, being constrained by the franchise agreement. In recruiting franchisees, franchisors themselves state the cliché that, 'In franchising, you are in business for yourself, but not by yourself'."

In an attempt to move the above stream of research forward, this article seeks to address the following key question: how entrepreneurial are franchisees? More particularly, our interest is in examining the personalities of franchisees and the extent to which these might be entrepreneurial. Understanding these issues can have important implications for both franchisor and franchisee satisfaction as well as for their organisational performance. By providing empirical evidence from both the franchisor's and the franchisee's perspectives, this paper addresses a major limitation associated with most franchising research. Many studies have focused solely on the franchisor and franchisee-based investigations are still relatively limited (see Dant, 2008). Since both franchise 
partners may have different perceptions about the franchising world, “... questions constantly arise about ... the applicability of franchisor-based research findings to the mindset of franchisees” (Dant, 2008, p. 92). Dant further argues that franchise researchers need to look beyond North America (and indeed the fast food sector) in order to advance our understanding of franchising. Thus, it is believed that by examining entrepreneurial tendencies within the UK context (and in different sectors) this paper can provide new insights into this phenomenon.

The rest of this paper is structured as follows: we begin in the next section by presenting a review of the relevant background studies, and the related hypotheses are developed. Then, the research design adopted to address the research question is described and justified, before reporting the results. Finally, the research implications, limitations, and directions for future research are presented.

\section{Literature review and hypotheses development}

Entrepreneurial tendencies

The literature on entrepreneurial tendencies focuses on recognising individuals with the inclination to behave entrepreneurially by considering aspects of personality that are characteristic of entrepreneurs (see, for example, Cromie, 2000). Both academics and practitioners appear to believe that, relative to any other factor, the success of a venture is more dependent on the individual entrepreneur (Lee and Tsang, 2001). Studies such as Collins et al. (2004), Rauch and Frese (2007a,b), Stewart and Roth (2007, 2001), Zhao et al. (2009), Gurel et al. (2010) and Brandstätter (2011) have revealed various findings, arguments, and meta-analytical evidence in support of the validity of personality traits as predictors of entrepreneurial behaviour, as well as established differences between entrepreneurs and other occupational groups such as managers.

Several personality traits of an entrepreneur have been investigated independently and collectively (Tajeddini and Mueller, 2009) to describe the entrepreneurial tendencies of an individual (Cromie, 2000). Our focus in this study is on five key personality traits: need for achievement, need for autonomy, internal locus of control, calculated risk-taking and creative tendency. These are some of the most established personality constructs that have been frequently associated with an entrepreneurial individual in both theoretical and empirical research (Ahmed, 1985; Cromie, 2000; Frank et al., 2007; Brandstätter, 2011).

Need for achievement (nAch). Emanating from McClelland's (1961) work, this is one of the most applied entrepreneurship theories (Littunen, 2000; Gürol and Atsan, 2006). It is believed that the 'need to achieve' motivates individuals to prevail over obstacles and difficult situations, and also motivates individuals to make every effort to attain their goals and excellence quickly (Tajeddini and Mueller, 2009, p. 8). Consequently, individuals with a high nAch are more likely to behave 
entrepreneurially (Koh, 1996) and most studies have found achievement to be a robust characteristic of successful entrepreneurs (Sebora et al., 2009).

Calculated risk-taking. Scholars have been contemplating the role of risk in entrepreneurial behaviour for more than 300 years (Stewart and Roth, 2001). The very nature of the entrepreneur's activities and role in society and economy suggests that entrepreneurs cannot be averse to taking risks (Kirby, 2004). Particular emphasis has been on differentiating entrepreneurs and professional managers on their risk-taking propensity, and a notable premise is that entrepreneurs personally take the risk of profit and loss (Gürol and Atsan, 2006).

Locus of control. Another trait that has received extensive attention is locus of control (Shane et al., 2003; Gürol and Atsan, 2006) which is based on Rotter's (1966) study. Locus of control refers to the extent to which individuals believe that they are able to influence events encountered in their lives (Lee and Tsang, 2001; Shane et al., 2003). Two types of individuals are involved in locus of control theory: (1) internals are those who believe that, on the whole, they are able to personally control life's events; and (2) externals are those who believe that life's events are the result of external factors, such as fate, luck, chance, or circumstances beyond their control (Lee and Tsang, 2001; Sebora et al., 2009). For entrepreneurship studies, the internal locus of control is more important than the external locus of control since entrepreneurship researchers are more interested in an individual's ability to perform (Wei and Ishmail, 2008).

Need for autonomy. "Need for autonomy is associated with entrepreneurs' avoidance of restrictive environments; they prefer to make decisions independent of supervisors, to set their own goals and develop their own plans of actions, and to control goal achievement themselves” (Rauch and Frese, 2007b, p. 359). As such, individualism and freedom are of great importance to entrepreneurs; they have an aversion to rules, procedures and social norms, and they have difficulty working in constraining environments that stifle creativity (Kirby, 2004).

Creative tendency. Creativity is the production of novel and useful ideas (Amabile et al., 1996). It has been seen as a link to innovation (Ko and Butler, 2007), which is defined as the successful implementation of creative ideas (Amabile et al., 1996). The entrepreneurship literature has devoted considerable attention to the entrepreneur's innovative ability (Stewart et al., 1998). Schumpeter (1934) depicted an entrepreneur as a person who undertakes new combinations. As noted by Stewart et al. (1998), these behaviours indicate a level of creative ability possessed by entrepreneurs, as demonstrated by their strategic behaviours.

Thus, by drawing upon these constructs of entrepreneurship, the entrepreneurial tendencies of franchisees can be determined. The following section, through a review of the relevant literature on franchising and entrepreneurship, develops a number of hypotheses which are then tested. We start by reviewing relevant literature on the entrepreneurial tendencies of the franchisor in order to enable comparison with those of the franchisee. 


\section{The franchisor's entrepreneurial tendencies}

Franchisors are generally characterised as entrepreneurs who typically start by operating a single outlet, or chain, and then grow their businesses by licensing the right to implement their concepts in dispersed geographical locations (Kaufmann and Dant, 1996). As such, the very act of creating a franchise network is an entrepreneurial act (Hoy and Shane, 1998). The mere decision by business owners to expand their businesses through the use of franchising may be considered highly innovative, judged from a human resource, financial or an ownership perspective (Stanworth et al., 2003). Hoy (2008, p. 153) described the arguments proposed about the creativity required in forming and growing franchise organisations, from the franchisor's perspective, in the following terms: “At some point in time, the franchisor created a venture. Subsequently, a strategic decision was made to grow the enterprise using a franchise model. That decision implies that management determined that the company offered something distinct to the marketplace, either expanding the market for the product or service or offering value that attracted customers from competitors”. Franchisors are thus entrepreneurs in part because of the risk involved in their attempt to build a franchise system (Ketchen et al., 2011). Therefore, it is expected that:

H1. Franchisors have high entrepreneurial tendencies.

H1a. Franchisors have a high need for achievement.

H1b. Franchisors have a high creative tendency.

H1c. Franchisors have a high propensity for calculated risk-taking.

H1d. Franchisors have a high internal locus of control.

H1e. Franchisors have a high need for autonomy.

\section{The franchisee's entrepreneurial tendencies}

Whereas the franchisor's role as an entrepreneur is generally assumed, the status of the franchisee remains highly controversial (see, for example, Falbe et al., 1998; Morrison, 2000; Clarkin and Rosa, 2005; Hoy, 2008; Ketchen et al., 2011; Dada et al., 2012; Dada and Watson, 2013). As discussed below, two main factors seem to have complicated this issue. These revolve around the franchisee personality and recruitment process.

Franchisee personality. One of the early studies in this area was conducted by Withane (1991), based on an analysis of 65 Canadian franchisees. It found that relative to the entrepreneurial characteristics reported to be necessary for successful franchise management (such as, need for achievement, autonomy, internal locus of control, risk-taking, initiative and self-reliance), franchisees had lower self-manifested levels on virtually all the entrepreneurship dimensions. In another study by Anderson et al. (1992), the Self Description Inventory developed by Ghiselli (1971) was used to compare the traits of franchisees and those of entrepreneurs. Their findings suggested that franchisees 
are not 'real' entrepreneurs because they do not have the same level of achievement motivation, supervisory ability, initiative, need for security or self-actualisation as entrepreneurs. Tuunanen and Hyrsky (2001) explored Finnish franchisees’ entrepreneurial characteristics. They found that Finnish franchisees were determined to succeed, they were self-confident, and they regarded themselves as customer-oriented people who took responsibility for their own actions. But many were predisposed to conforming behaviour. Paswan and Johns (2007) used a slightly different approach by exploring whether a franchisee is an entrepreneur, or an employee. Their findings revealed that, when compared to those respondents who currently work for an existing firm, both existing and prospective owners of an independent business tend to view being a franchisee as an employee. More recently, Weaven et al. (2009) found significant differences in the personalities of their sample of Australian franchisees using psychological measures. These results, according to the authors, suggest that standard personality measures are valuable for differentiating franchisees that have the potential to undertake different behaviours within franchise systems. In general, franchisees appear to be perceived more as ‘controlled self-employed' (Felstead, 1991). Hence, it is expected that:

H2. Franchisees have low entrepreneurial tendencies.

H2a. Franchisees have a low need for achievement.

$H 2 b$. Franchisees have a low creative tendency.

H2c. Franchisees have a low propensity for calculated risk-taking.

H2d. Franchisees have a low internal locus of control.

H2e. Franchisees have a low need for autonomy.

Furthermore, Williams’ (1998) findings suggested that when compared to those entrepreneurs who choose to establish an independent business, franchisee entrepreneurs have lower skills and they use franchising to reduce demand uncertainty pertaining to their products and locations. Therefore, it is expected that an entrepreneur with a greater aversion to risk will prefer the franchisee route (Williams, 1998). DiPietro et al. (2007, p. 64) also found that franchisees had lower levels of hope than franchisors probably because "in a franchise system, the franchisor is seen as the entrepreneur and the franchisee is considered less of a risk taker”. As a result, starting a franchise outlet may be considered less entrepreneurial than founding a firm from 'scratch' because a concept that has already been developed is purchased, and accordingly, less risk and innovation is involved (Verheul et al., 2005). Besides, since franchisees often operate in communities that are well known to them, as a result of having lived in such areas for a long time (Bürkle and Posselt, 2008), they have insights into local needs and they are more familiar with the local environment and its potential; as such, the risk they face in running their outlets may be reduced by this familiarity (Kaufmann and Dant, 1999; Combs et al., 2004). Thus, it is hypothesised that:

H3. Franchisors have higher entrepreneurial tendencies than franchisees. 
H3a. Franchisors have a higher need for achievement than franchisees.

$H 3 b$. Franchisors have a higher creative tendency than franchisees.

H3c. Franchisors have a higher propensity for calculated risk-taking than franchisees.

H3d. Franchisors have a higher internal locus of control than franchisees.

H3e. Franchisors have a higher need for autonomy than franchisees.

Franchisee recruitment. Another major factor which seems to have complicated the franchisee's entrepreneurial position relates to the franchisee recruitment process. The selection of appropriate franchisees appears to be the franchisor's single most pervasive operating problem (Jambulingam and Nevin, 1999). Without a doubt, the careful selection of appropriate franchisees plays a vital role in the maintenance of a healthy franchisor-franchisee relationship and in the growth of the franchisor's system (Clarkin and Swavely, 2003; 2006). In spite of the recognised importance of the franchisee selection process, very little scholarly attention has been devoted to it (Jambulingam and Nevin, 1999). Nevertheless, franchisors often state that they prefer to select a manager, rather than an entrepreneur, as a franchisee in order to protect their business systems from unauthorised change (Falbe et al., 1998). A major concern is that franchisees may behave opportunistically to the disadvantage of the franchisor, by willfully disregarding the franchisor's goals as well as deviating from the franchisor's proven procedures, in pursuit of their own entrepreneurial interests (Baucus et al., 1996; Gassenheimer et al., 1996). Hence, it is hypothesised that:

H4. Franchisors seek franchisees with low entrepreneurial tendencies.

\section{Methodology}

In order to consider the appropriateness of the hypotheses, a preliminary focus group was conducted with eight international academic experts at a conference of the International Society of Franchising (ISoF). Although we exerted considerable efforts on trying to organise focus groups for franchise practitioners, these proved impossible eventually. Nevertheless, given that most of the academics that took part in the focus group had extensive experience with franchising, especially through their research and consultancy work, the academic focus group was deemed adequate. Academic experts that took part in the focus group comprised renowned professors, University lecturers, researchers and $\mathrm{PhD}$ candidates from the US, Europe and Australia, who had undertaken substantial relevant work in the present research area. The ISoF is arguably the foremost, multidisciplinary and multinational academic conference for franchising research (see www.huizenga.nova.edu/ExecEd/ISoF). The focus group session lasted for 60 minutes and the discussion was tape-recorded and later transcribed for analysis purposes. After the focus group, two 
separate follow-up surveys were then conducted for the main study, one for franchisors and another for their franchisees, as discussed below.

\section{Sample selection}

The franchisor's sampling frame comprised the attendees of a major British Franchise Association's (BFA) event, the National Franchise Exhibition. The BFA is the only independent accreditation body, promoting ethical franchising in the UK. Permission to have the survey at this event was obtained from both the Director General and the President of the Association. About 209 franchisors were present at the exhibition; approximately 67 percent agreed to participate in the study, bringing the number of questionnaires distributed to 141 . Following a series of reminders (phone calls, e-mails and follow-up letters), a total of 55 completed questionnaires were returned, giving a 39 percent response rate. T-test comparisons of the respondents and nonrespondents, on age of the franchise system, defined as the number of years the company has been franchising in the UK ( $t=1.13, p=0.26)$; and the size of the franchise system, defined as the number of franchise outlets that the company has in the UK $(t=0.48, p=0.64)$, did not reveal statistically significant differences between the two groups. We also found no bias between early and late respondents. Therefore, we concluded that non-response bias is unlikely to be an issue in the interpretation of the findings from this study. The respondents were mainly the founders and owner-managers of the franchise organisations; as such, they had sufficient knowledge of the firm's franchise policies.

The average age of the respondents' systems was 8.30 years; the average number of franchise outlets per system was approximately 66; and the franchisors were from 10 industry sectors: (1) Retailing; (2) Property and maintenance services, and home improvements; (3) Catering and hotels; (4) Cleaning and renovation services; (5) Commercial services; (6) Direct selling, distribution, wholesaling, and vending; (7) Domestic, personal, health and fitness, caring, and pet services; (8) Employment agencies, executive search, management consultancy, training and teaching; (9) Estate agents, business transfer agents, financial services and mortgage brokers; (10) Printing, copying, and graphic design. The sectors were based on the information provided in the Franchise World Directory (2005).

During the franchisors' survey, the respondents were asked to indicate on their completed questionnaires if they would be prepared for their franchisees to be surveyed too. Seven systems expressed an interest in this, and a total of 182 questionnaires were mailed to their franchisees. In addition to a copy of the questionnaire, the mailing included a cover letter and a postage-paid reply envelope. About 3 weeks after the initial mailing, a reminder mailing was sent out to those who had not responded. Following a series of reminders, 48 completed questionnaires were returned, giving a 26 percent overall response rate (inter-system response rate ranged from 12 to 50 percent). No bias between early and late respondents was found. The respondents were mainly the owner- 
managers of the franchised outlets. The average age of respondents' outlets was 2.47 years; the average number of outlets owned by respondents was two; and they were from five industry sectors: (1) Property and maintenance services, and home improvements; (2) Commercial services; (3) Direct selling, distribution, wholesaling, and vending; (4) Estate agents, business transfer agents, financial services and mortgage brokers; (5) Business support and business networking. The sectors were based on the information provided in the Franchise World Directory (2005).

\section{Questionnaire and analysis}

A notable established instrument, the Durham University General Enterprising Tendency (GET) test developed by Johnson and Caird (1988), was adopted to assess the entrepreneurial tendencies of both franchisors and franchisees. This test measures the respondent's propensity to take calculated risks, creative tendency, need for achievement, need for autonomy and internal locus of control. The GET test consists of 54 statements that require an 'agree' or 'disagree' response. 'Correct' responses score one point, giving a maximum possible score of 54. As highlighted by Cromie (2000, p. 22), “the GET test is comprehensive, [it] has criterion and convergent validity and good internal consistency”. This test has been utilised in previous entrepreneurship studies such as Caird (1991), Henry et al. (2004) and Kirby (2004). Prior to the survey, the questionnaires were piloted with some franchisors and some of the academics that took part in the preliminary focus group.

The hypotheses were tested using SPSS for Windows 13.0 software, and the Mann-Whitney $\mathrm{U}$ test was used to examine whether statistically significant differences exist between the franchisors' and the franchisees' responses. This non-parametric test was particularly useful for the analysis as it accounted for the small sample sizes.

\section{Results}

Entrepreneurial tendencies of franchisors and franchisees

Table 1 contains a summary of the GET scores of the franchise partners. For comparative purposes, the table also shows the maximum and the average scores for the GET test. The franchisors' and the franchisees' total GET scores were 40.55 and 39.33 respectively, out of a maximum possible score of 54. These were above the standard, average entrepreneurial tendency score of 37 (according to the GET measure), implying that franchisors and franchisees both have above-average entrepreneurial tendencies. In addition, no statistically significant differences were found on the franchisors' and the franchisees' total GET scores. Hence, the following hypothesis was supported: H1 (Franchisors have high entrepreneurial tendencies), but the following hypotheses were not supported: H2 (Franchisees have low entrepreneurial tendencies) and H3 (franchisors have higher entrepreneurial tendencies than franchisees). These suggest that both franchisors and franchisees should be regarded as 
entrepreneurs, and franchisors are not significantly more entrepreneurial than franchisees as is widely believed. Their disaggregated scores are explained below.

\section{Insert Table I about here.}

Need for achievement. Both franchisors and franchisees appeared to have a fairly high need for achievement, signifying a high tendency to set challenging goals and a high planning orientation for success (see Caird, 1991). These provide support for H1a (Franchisors have a high need for achievement) but not for H2a (Franchisees have a low need for achievement). There were also no statistically significant differences in their tendencies on this entrepreneurial dimension, thus providing no support for HЗa (Franchisors have a higher need for achievement than franchisees).

The fairly high scores obtained by both franchisors and franchisees on creative tendency suggest that they have an imaginative and an innovative orientation, versatility, a preference for novelty, intuition, a tendency to have ideas and sensitivity to opportunity (see Caird, 1991). These provide support for H1b (Franchisors have a high creative tendency) but not for H2b (Franchisees have a low creative tendency). Again, no statistically significant differences were observed in the tendencies of both franchise partners on this entrepreneurial dimension, thus providing no support for $H 3 b$ (Franchisors have a higher creative tendency than franchisees).

Their moderately high scores on calculated risk-taking indicate that they both have the ability to make decisions in uncertain conditions and they are capable of judging that a risk is worth taking when the consequences of failure do not outweigh the incentive value of success (see Caird, 1991). Thus, H1c (Franchisors have a high propensity for calculated risk-taking) was supported, while H2c (Franchisees have a low propensity for calculated risk-taking) was not supported. Similar to the above, the franchise partners' scores were not statistically significantly different from each others' on this entrepreneurial element, thus lending no support for H3c (Franchisors have a higher propensity for calculated risk-taking than franchisees).

The high scores obtained by both franchisors and franchisees on internal locus of control suggest that they are proactive, self-reliant, self-determined, self-confident and they believe that achievement is due to ability and effort (see Caird, 1991). Thus, H1d (Franchisors have a high internal locus of control) was supported, while H2d (Franchisees have a low internal locus of control) was not supported. As with the above dimensions of entrepreneurship, no statistically significant differences were found between the franchise partners' scores on this element of entrepreneurship, thus providing no support for H3d (Franchisors have a higher internal locus of control than franchisees).

Interestingly, the franchisors' and the franchisees' scores were slightly below the average on need for autonomy, and their scores were not statistically significantly different from each others'. 
Their low scores demonstrate that they both have a facilitating nature, flexibility with decisionmaking and a preference for working with, or for others, rather than managing others (see Caird, 1991). Therefore, the following hypotheses were not supported: H1e (Franchisors have a high need for autonomy) and H3e (Franchisors have a higher need for autonomy than franchisees). But H2e (Franchisees have a low need for autonomy) was supported.

\section{Franchisee selection}

Surprisingly, franchisors indicated that to a large extent they seek to recruit franchisees who possess entrepreneurial qualities, notably ambitious people, independent people, creative people, risk takers and people who like to be in control. These entrepreneurial qualities were adapted from the GET test. The mean ratings obtained ranged from 3.15 to 4.37 across all the five entrepreneurial qualities (on a 5-point rating scale). This may help to explain the franchisees' entrepreneurial tendencies highlighted in the prior section. Presumably, if franchisors do not recruit entrepreneurs, franchisees would not have been found to possess above-average entrepreneurial tendencies. In addition, approximately 59 percent of the franchisors utilised a standard selection system (such as psychometric tests and interview techniques), during the franchisee selection process, to identify whether or not a prospective franchisee is entrepreneurial. Thus, the following hypothesis was not supported: H4 (franchisors seek franchisees with low entrepreneurial tendencies).

\section{Discussion}

The findings demonstrate that despite enduring arguments in the literature suggesting that franchisees are not entrepreneurs, there is evidence to the contrary. The results here show that franchisees exhibit entrepreneurial traits, and have similar entrepreneurial tendencies to their franchisors. Indeed, not only do franchisees possess entrepreneurial tendencies, but these are actively sought by franchisors in the recruitment process. These findings would appear to refute the contention put forward in Ketchen et al.'s (2011) study, that franchisees cannot be considered as entrepreneurs as they follow a manual, offer little or no innovation, typically do not identify opportunities, take on less risk (than the franchisor), and merely exploit opportunities that have already been identified (by the franchisor). Of course, Ketchen et al. (op. cit.) considered entrepreneurial behaviours rather than characteristics, but if franchisors did not wish their franchisees to engage in entrepreneurial behaviours it would seem strange to actively seek franchisees that exhibited entrepreneurial tendencies (personalities). If entrepreneurial franchisees are not granted sufficient autonomy and/or the opportunity for innovation, they are likely to become dissatisfied with the franchise relationship, and their frustrations are likely to cause conflict within the system (Davies et al., 2011). Thus, given the presence of entrepreneurial tendencies it would 
seem logical that franchisees will also engage in entrepreneurial behaviours, although the type and nature of these activities need further exploration.

It was interesting to note from the findings that the one dimension in which franchisees (and franchisors) exhibited slightly lower than average scores, was the need for autonomy. This lower score suggests a more facilitating nature, and a preference for working with (or for) others (Caird, 1991). In the context of a franchise system, this lower score should perhaps come of little surprise in recruiting franchisees, franchisors affectively surrender substantial control to the franchised outlets (Castrogiovanni et al., 2006b). Franchisees invest in the franchisor, paying for the right to use the franchisors brand name and business system while agreeing to adhere to the performance standards required by the franchisor. Thus, presumably both franchisor and franchisee, in entering the franchise relationship understand the need to work together. The findings here thus confirm Baucus et al.'s (1996, p. 359) view of franchising as a “cooperative arrangement among entrepreneurs”.

\section{Academic implications}

In all, the research findings offer important research implications towards a clarification of the franchisees' entrepreneurial status, a widely unclear research area. Franchisee-based studies are generally limited in franchising research (Dant, 2008) and this is especially so in the entrepreneurship field. Indeed, Seawright et al. (2011, p. 1-2) stressed that as the intersection of franchising and entrepreneurship literatures continues to develop, more studies are needed to better understand the extent to which franchisees differ from other entrepreneurs, as the results of these would have implications "for the inclusion of franchisees in study designs and theory-building in entrepreneurship research”. The results here would suggest that franchisees can be considered as entrepreneurs, and as such the findings are of particular pertinence for future studies exploring issues around franchise performance, relationship management, and control.

\section{Practitioner implications}

This research also offers important managerial implications for practitioners to improve the franchisor-franchisee relationship. Whilst some franchisors might have recognised the value of fostering an entrepreneurial climate within their systems, many have upheld the argument that providing space for entrepreneurship may be damaging to the franchising sector. The main concern is that franchisees with high entrepreneurial tendencies may begin to free ride to the disadvantage of the entire system. For instance, some franchisees adapt to their local contexts so much that they deviate from the franchisor's standardised format and even change the nature of the franchise concept (Akremi et al., 2011) possibly because of the franchisees’ high entrepreneurial tendencies. A recent study by Dada et al. (2012, p. 1) found examples of franchisors who felt that 
entrepreneurial franchisees cannot thrive in the franchise environment. Perhaps indicative of the views of some franchisors is Robert L. Purvin Jr., Chairman and CEO of the American Association of Franchisees and Dealers (quoted in Morrow, 2011) who stated that :

There should be a sign out in front of every franchise that says, 'Entrepreneurs need not apply’.

Having demonstrated in this study that franchisees seem to have similar levels of entrepreneurial tendencies to franchisors, the question should neither be about prohibiting entrepreneurial individuals from becoming franchisees nor restraining existing franchisees from acting entrepreneurially. Rather, the franchisor's challenge should centre on instituting measures to manage entrepreneurial behaviours successfully amongst franchisees, within the standardised context of the franchise system. Indeed, recent studies have found that the recruitment of entrepreneurial franchisees has a significant positive impact on the franchise relationship quality (Dada and Watson, 2012), and that for franchise organisations, entrepreneurial orientation has a positive impact on system performance (Dada and Watson, 2013). Overall, the findings from the present study align with the argument that franchising can be viewed as a type of entrepreneurial organisation (Tuunanen and Hoy, 2007).

\section{Limitations and recommendations for further research}

A limitation of this study relates to the fact that there are usually concerns associated with the use of non-random samples. The sampling frame for the survey was the attendees of a major franchise event in the UK, the National Franchise Exhibition. This event was specifically chosen in order to attract a high number of participants for the study, due to its popularity with both franchisors and franchisees, and also because the objective of the exhibition (franchisee recruitment) closely matched a key area of interest in this research. Nevertheless, clear limits for generalisations from this study pertain to the sampling frame for the surveys and to the composition of respondents, which involved somewhat small sample sizes. However, we accounted for this with the use of relevant non-parametric test. Furthermore, it is worth noting that it was impossible to examine the representativeness of the sample, as we are unaware of any database in the UK which contains comprehensive details on the age and size dimensions of every franchisor-owned organisation and franchisee-owned outlets. In addition, since the questionnaires were self-completed, the results from the measurement instruments may depend on the extent to which respondents were able to accurately report their level of agreement or feelings with regards to the survey items (Weaven et al., 2009).

Future research could explore not just entrepreneurial tendencies (traits) but also entrepreneurial behaviours by franchisees, given the potential limitations of a one-dimensional 
approach in capturing entrepreneurship (Maes, 2003). In addition, research that includes a larger sample (of both franchisors and franchisees) would enable potential differences to be explored between the length of time the franchisee has been in the system, the age and size of the franchise system, and the entrepreneurial tendencies/activities of the franchisees. Researchers (for example, Blut et al., 2010; Davies et al., 2011) have suggested that that there may be lifecycle affects within the franchise relationship. Davies et al. (2011) argue that as the franchise relationship matures and franchisees gain confidence, that their aspirations for entrepreneurial autonomy will develop. In addition, younger franchise systems may seek innovative and autonomous franchisees to help them grow their system, but as it matures, issues of control and uniformity may dominate. This may also lead to differences in preference for franchisee characteristics as the system matures.

\section{Conclusions}

This study demonstrates that franchisees and franchisors have similar levels of aggregate entrepreneurial tendency (comprising need for achievement, creative tendency, calculated risktaking, internal locus of control and need for autonomy). When disaggregated into the individual dimensions, both franchisors and franchisees also had similar levels of entrepreneurial tendencies. Additionally, we found that franchisors appear to value entrepreneurial personalities within their franchised outlets, as demonstrated by their franchisee selection process which showed that, to a large extent, franchisors seek to recruit franchisees who possess entrepreneurial qualities (notably, ambitious people, independent people, creative people, risk takers and people who like to be in control). Thus, future studies exploring franchising should consider the relational exchange as one of a partnership between entrepreneurs. For practitioners the study suggests that given franchisees possess entrepreneurial characteristics, careful consideration needs to be given as to how to develop structures and approaches to managing entrepreneurs within the standardised context of a franchise network. Overall, this study contributes to a growing body of research, and hopefully will provide a catalyst for further research into the entrepreneurial role of the franchisee, so that greater insights can be generated as to how to manage entrepreneurs within a franchise context.

\section{References}

Ahmed, S.U. (1985), “nAch, risk-taking propensity, locus of control and entrepreneurship”, Personality and Individual Differences, Vol. 6 No. 6, pp. 781-782.

Akremi, A., Mignonac, K. and Perrigot, R. (2011), “Opportunistic behaviours in franchise chains: The role of cohesion among franchisees”, Strategic Management Journal, Vol. 32 Issue 9, pp. 930-948.

Amabile, T.M., Conti, R., Coon, H., Lazenby, J. and Herron, M. (1996), “Assessing the work 
environment for creativity”, Academy of Management Journal, Vol. 39 No. 5, pp. 11541184.

Anderson, R.L., Condon, C. and Dunkelberg, J. (1992), “Are franchisees 'real' entrepreneurs?”, Journal of Business and Entrepreneurship, Vol. 4 No. 1, pp. 97-104.

Baucus, D.A., Baucus, M.S. and Human, S.E. (1996), “Consensus in franchise organisations: A cooperative arrangement among entrepreneurs”, Journal of Business Venturing, Vol. 11 No. 5, pp. 359-378.

Brandstätter, H. (2011), “Personality aspects of entrepreneurship: A look at five metaanalyses”, Personality and Individual Differences, Vol. 51 Issue 3, pp. 222-230.

Bürkle, T. and Posselt, T. (2008), “Franchising as a plural system: A risk-based explanation”, Journal of Retailing, Vol. 84 No. 1, pp. 39-47.

Caird, S. (1991), “Testing enterprising tendency in occupational groups”, British Journal of Management, Vol. 2 No. 4, pp. 177-186.

Castrogiovanni, G.J., Combs, J.G. and Justis, R.T. (2006a), “Resource scarcity and agency theory predictions concerning the continued use of franchising in multi-outlet networks", Journal of Small Business Management, Vol. 44 No. 1, pp. 27-44.

Castrogiovanni, G.J., Combs, J.G. and Justis, R.T. (2006b), “Shifting imperatives: An integrative view of resource scarcity and agency reasons for franchising”, Entrepreneurship Theory and Practice, Vol. 30 No. 1, pp. 23-40.

Clarkin, J.E. and Rosa, P.J. (2005), “Entrepreneurial teams within franchise firms”, International Small Business Journal, Vol. 23 No. 3, pp. 303-334.

Clarkin, J.E. and Swavely, S.M. (2003), "How franchisors choose franchisees: A comparison of prospective franchisee evaluation criteria”, in proceedings of the $17^{\text {th }}$ Annual International Society of Franchising Conference, 15-18 February, San Antonio, Texas.

Clarkin, J.E. and Swavely, S.M. (2006), “The importance of personal characteristics in franchisee selection”, Journal of Retailing and Consumer Services, Vol. 13 No. 2, pp. 133142.

Collins, C.J., Hanges, P.J. and Locke, E.E. (2004), “The relationship of achievement motivation to entrepreneurial behaviour: A meta-analysis”, Human Performance, Vol. 17 No. 1, pp. 95-117.

Combs, J.G., Ketchen, D.J. and Hoover, V.L. (2004), “A strategic groups approach to the franchising-performance relationship”, Journal of Business Venturing, Vol. 19 Issue 6, pp. 877-897. 
Cromie, S. (2000), “Assessing entrepreneurial inclinations: Some approaches and empirical evidence”, European Journal of Work and Organisational Psychology, Vol. 9 No. 1, pp. 730.

Dada, O. and Watson, A. (2013), “Entrepreneurial orientation and the franchise system: Organisational antecedents and performance outcomes”, European Journal of Marketing, Vol. 47 No. 5/6, pp. 790-812.

Dada, O. and Watson, A. (2012), “The effect of entrepreneurial orientation on the franchise relationship”, International Small Business Journal, Vol. 31 No.8, pp. 955-977.

Dada, O., Watson, A. and Kirby, D. (2012), “Toward a model of franchisee entrepreneurship”, International Small Business Journal, Vol. 30 No. 5, pp. 559-583.

Dant, R.P. (2008), “A futuristic research agenda for the field of franchising”, Journal of Small Business Management, Vol. 46 No. 1, pp. 91-98.

Davies, M.A.P, Lassar, W., Manolis, C., Prince, M. and Winsor, R.D. (2011), “A model of trust and compliance in franchise relationships”, Journal of Business Venturing, Vol. 26 No. 3, pp. 321-340.

DiPietro, R.B., Welsh, D.H.B., Raven, P.V. and Severt, D. (2007), “A measure of hope in franchise systems: Assessing franchisees, top executives, and franchisors”, Journal of Leadership and Organisational Studies, Vol. 13 No. 3, pp. 59-66.

Durham University Business School (1988), The General Enterprising Tendency test, Durham, UK.

Falbe, C.M., Dandridge, T.C. and Kumar, A. (1998), “The effect of organisational context on entrepreneurial strategies in franchising”, Journal of Business Venturing, Vol. 14 No. 1, pp. 125-140.

Felstead, A. (1991), "The social organisation of the franchise: A case of 'controlled selfemployment”, Work, Employment and Society, Vol. 5 No. 1, pp. 37-57.

Franchise Navigator, www.franchise-navigator.com (accessed 6 June 2012).

Frank, H., Lueger, M. and Korunka, C. (2007), “The significance of personality in business start-up intentions, start-up realisation and business success”, Entrepreneurship and Regional Development, Vol. 19 No. 3, pp. 227-251.

Franchise World (2005), Franchise World Directory, UK.

Gassenheimer, J.B., Baucus, D.B. and Baucus, M.S. (1996), “Cooperative arrangements among entrepreneurs: An analysis of opportunism and communication in franchise structures”, Journal of Business Research, Vol. 36 No. 1, pp. 67-79.

Ghiselli, E.E. (1971), Explorations in Managerial Talent, Goodyear Publishing Company, Inc, Pacific Palisades, CA.

Gurel, E., Altinay, L. and Daniele, R. (2010), “Tourism students’ entrepreneurial intentions”, 
Annals of Tourism Research, Vol. 37 No. 3, pp. 646-669.

Gürol, Y. and Atsan, N. (2006), “Entrepreneurial characteristics amongst University students: Some insights for entrepreneurship education and training in Turkey”, Education and Training, Vol. 48 Issue 1, pp. 25-38.

Henry, C., Hill, F.M. and Leitch, C.M. (2004), “The effectiveness of training for new business creation: A longitudinal study”, International Small Business Journal, Vol. 22 No. 3, pp. 249-271.

Hoy, F., Stanworth, J. and Purdy, D. (2000), “An entrepreneurial slant to franchise research”, in Sexton, D.L. and Landstrom, H. (Ed.), The Blackwell Handbook of Entrepreneurship, Blackwell Business, pp. 408-432.

Hoy, F. (2008), “Organisational learning at the marketing/ entrepreneurship interface”, Journal of Small Business Management, Vol. 46 No. 1, pp. 152-158.

Hoy, F. and Shane, S. (1998), “Franchising as an entrepreneurial venture form”, Journal of Business Venturing, Vol. 13 No. 2, pp. 91-94.

Jambulingam, T. and Nevin, J.R. (1999), "Influence of franchisee selection criteria on outcomes desired by the franchisor”, Journal of Business Venturing, Vol. 14 No. 4, pp. 363-395.

Johnson, C. and Caird, S. (1988), The Measurement of General Enterprising Tendency, Durham University Business School, Durham, UK.

Kaufmann, P.J. and Dant, R.P. (1996), “Multi-unit franchising: Growth and management issues”, Journal of Business Venturing, Vol. 11 No. 5, pp. 343-358.

Kaufmann, P.J. and Dant, R.P. (1999), "Franchising and the domain of entrepreneurship research”, Journal of Business Venturing, Vol. 14 No. 1, pp. 5-16.

Ketchen, D.J., Short, J.C. and Combs, J.G. (2011), “Is franchising entrepreneurship? Yes, no, and maybe so”, Entrepreneurship Theory and Practice, Vol. 35 Issue 3, pp. 583-593.

Kirby, D.A. (2004), “Entrepreneurship education: Can business schools meet the challenge?” Education and Training, Vol. 46 No. 8/9, pp. 510-519.

Ko, S. and Butler, J.E. (2007), “Creativity: A key link to entrepreneurial behaviour”, Business Horizons, Vol. 50 Issue 5, pp. 365-372.

Koh, H.C. (1996), “Testing hypotheses of entrepreneurial characteristics: A study of Hong Kong MBA students”, Journal of Managerial Psychology, Vol. 11 No. 3, pp. 12-25.

Lee, D.Y. and Tsang, E.W.K. (2001), “The effects of entrepreneurial personality, background and network activities on venture growth”, Journal of Management Studies, Vol. 38 No. 4, pp. 583-602.

Littunen, H. (2000), “Entrepreneurship and the characteristics of the entrepreneurial personality”, International Journal of Entrepreneurial Behaviour and Research, Vol. 6 No. 6, pp. 295-309. 
Maes, J. (2003), “The search for corporate entrepreneurship: A clarification of the concept and its measures”, working paper, Katholieke Universiteit Leuven- Department of Applied Economics Organisation Studies.

McClelland, D.C. (1961), The Achieving Society, Van Nostrand, Princeton, NJ.

Michael, S.C. and Combs, J.G. (2008), “Entrepreneurial failure: The case of franchisees”, Journal of Small Business Management, Vol. 46 No. 1, pp. 73-90.

Morrison, K.A. (1997), “How franchise job satisfaction and personality affects performance, organisational commitment, franchisor relations, and intention to remain”, Journal of Small Business Management, July, pp. 39-67.

Morrison, A. (2000), “Entrepreneurs or intrapreneurs”, in Lashley, C. and Morrison, A. (Ed.), Franchising Hospitality Services, Butterworth-Heinemann, Oxford.

Morrow, E.S. (2011), “Is franchising right for you? Not all entrepreneurs thrive on a predetermined business model”, Black Enterprise, Vol. 41 No 9, pp. 72-76.

Paswan, A. and Johns, R. (2007), "Is a franchisee entrepreneur or employee? An exploratory investigation of perceptions about being a franchisee", in proceedings of the $21^{\text {st }}$ Annual International Society of Franchising Conference, 24-25 February, Las Vegas, Nevada.

PricewaterhouseCoopers (2008), The Economic Impact of Franchised Businesses. Volume II: Results for 2005, prepared for The International Franchise Association Educational Foundation.

Rauch, A. and Frese, M. (2007a), "Born to be an entrepreneur? Revisiting the personality approach to entrepreneurship”, in Baum, R.J., Frese, M. and Baron, R. (Ed.), The Psychology of Entrepreneurship, Lawrence Erlbaum Associates, Mahwah, NJ, pp. 41-66.

Rauch, A. and Frese, M. (2007b), “Let’s put the person back into entrepreneurship research: A meta-analysis on the relationship between business owners personality traits, business creation, and success”, European Journal of Work and Organisational Psychology, Vol. 16, pp. 353-385.

Rotter, J.B. (1966), “Generalised expectancies for internal versus external locus of control of reinforcement”, Psychological Monographs: General and Applied, Vol. 80, pp. 1-28.

Schumpeter, J.A. (1934), The Theory of Economic Development, Harvard University Press, Cambridge, MA.

Seawright, K.W., Smith, I.H., Mitchell, R.K. and McClendon, R. (2011), “Exploring entrepreneurial cognition in franchisees: A knowledge-structure approach”, Entrepreneurship Theory and Practice, May, pp. 1-27.

Sebora, T.C., Lee, S.M. and Sukasame, N. (2009), “Critical success factors for e-commerce 
entrepreneurship: An empirical study of Thailand”, Small Business Economics, Vol. 32 No. 3, pp. 303-316.

Shane, S., Locke, E.A. and Collins, C.J. (2003), “Entrepreneurial motivation”, Human Resource Management Review, Vol. 13, pp. 257-279.

Sorenson, O. and Sørensen, J.B. (2001), “Finding the right mix: Franchising, organisational learning, and chain performance”, Strategic Management Journal, Vol. 22, pp. 713-724.

Spinelli, S., Rosenberg, R.M. and Birley, S. (2004), Franchising: Pathway to Wealth Creation, Financial Times Prentice Hall, Harlow.

Stanworth, J., Healeas, S., Purdy, D., Watson, A. and Stanworth, C. (2003), "Entrepreneurial teams, intellectual capital acquisition and knowledge management - new perspectives on franchising as a small business growth strategy", in proceedings of the Society of Franchising, San Antonio, Texas.

Stewart, W.H., Stewart, W.E., Carland, J.C. and Carland, J.W. (1998), “A proclivity for entrepreneurship: A comparison of entrepreneurs, small business owners, and corporate managers”, Journal of Business Venturing, Vol. 14, pp. 189-214.

Stewart, W.H. and. Roth, P.L (2001), “Risk propensity differences between entrepreneurs and managers: A meta-analytic review”, Journal of Applied Psychology, Vol. 86 No. 1, pp. 145-153.

Stewart, W.H. and Roth, P.L. (2007), “A meta-analysis of achievement motivation differences between entrepreneurs and managers”, Journal of Small Business Management, Vol. 45 No. 4, pp. 401-421.

Tajeddini, K. and Mueller, S.L. (2009), "Entrepreneurial characteristics in Switzerland and the UK: A comparative study of techno-entrepreneurs”, Journal of International Entrepreneurship, Vol. 7, pp. 1-25.

Tuunanen, M (2007), “Franchising as entrepreneurial activity: Finnish SME policy perspective”, in Economics and Management of Networks, Contributions to Management Science, Part A: Part 4, pp. 213-233.

Tuunanen, M and Hoy, F (2007), “Franchising - Multifaceted form of entrepreneurship”, International Journal of Entrepreneurship and Small Business, Vol. 4 No. 1, 52-67.

Tuunanen, M. and Hyrsky, K. (2001), “Entrepreneurial paradoxes in business format franchising: An empirical survey of Finnish franchisees”, International Small Business Journal, Vol. 19 No. 4, pp. 47-62.

Verheul, I., Uhlaner, L. and Thurik, R. (2005), “Business accomplishments, gender and entrepreneurial self-image”, Journal of Business Venturing, Vol. 20 No. 4, pp. 483518.

Weaven, S., Grace, D. and Manning, M. (2009), “Franchisee personality: An examination in 
the context of franchise unit density and service classification”, European Journal of Marketing, Vol. 43 No. 1/2, pp. 90-109.

Wei, O.J. and Ishmail, H.B. (2008), “Revisiting personality traits in entrepreneurship study from resource-based perspective”, Business Renaissance Quarterly, Vol. 3 No. 1, pp. 97114.

Williams, D.L. (1998), "Why do entrepreneurs become franchisees? An empirical analysis of organisational choice”, Journal of Business Venturing, Vol. 14 No. 1, pp. 103-124.

Withane, S. (1991), "Franchising and franchisee behaviour: An examination of opinions, personal characteristics, and motives of Canadian franchisee entrepreneurs”, Journal of Small Business Management, Vol. 29 No. 1, pp. 22-30.

Zhao, H., Seibert, S.E. and Lumpkin, G.T. (2010), “The relationship of personality to entrepreneurial intentions and performance: A meta-analytic review”, Journal of Management, Vol. 36 No. 2, pp. 381-404. 


\begin{tabular}{|c|c|c|c|c|c|c|}
\hline \multirow[t]{2}{*}{ Group } & $\begin{array}{c}\text { Need for } \\
\text { achievement }^{\mathrm{a}}\end{array}$ & $\begin{array}{c}\text { Need for } \\
\text { autonomy/ } \\
\text { independence }\end{array}$ & $\begin{array}{l}\text { Creative } \\
\text { tendency }^{\mathrm{a}}\end{array}$ & $\begin{array}{l}\text { Calculated } \\
\text { risk-taking }^{\mathrm{a}}\end{array}$ & $\begin{array}{l}\text { Internal } \\
\text { locus of } \\
\text { control }^{\text {a }}\end{array}$ & Total score ${ }^{a}$ \\
\hline & $\begin{array}{l}12^{\mathrm{b}} \\
9^{\mathrm{c}} \\
\end{array}$ & $\begin{array}{l}6^{\mathrm{b}} \\
4^{\mathrm{c}} \\
\end{array}$ & $\begin{array}{l}12^{\mathrm{b}} \\
8^{\mathrm{c}} \\
\end{array}$ & $\begin{array}{l}12^{\mathrm{b}} \\
8^{\mathrm{c}} \\
\end{array}$ & $\begin{array}{c}12^{\mathrm{b}} \\
8^{\mathrm{c}} \\
\end{array}$ & $\begin{array}{l}54^{\mathrm{b}} \\
37^{\mathrm{c}} \\
\end{array}$ \\
\hline $\begin{array}{l}\text { Franchisors }^{\mathrm{d}} \\
N=54\end{array}$ & $\begin{array}{c}9.61 \\
(1.79)\end{array}$ & $\begin{array}{l}3.81 \\
(1.44)\end{array}$ & $\begin{array}{l}8.70 \\
(2.04)\end{array}$ & $\begin{array}{r}8.89 \\
(1.88)\end{array}$ & $\begin{array}{c}9.54 \\
(1.89)\end{array}$ & $\begin{array}{l}40.55 \\
(5.72)\end{array}$ \\
\hline $\begin{array}{l}\text { Franchisees }^{\mathrm{d}} \\
N=46\end{array}$ & $\begin{array}{l}9.83 \\
(1.32)\end{array}$ & $\begin{array}{l}3.59 \\
(1.50)\end{array}$ & $\begin{array}{l}8.30 \\
(2.00)\end{array}$ & $\begin{array}{l}8.26 \\
(2.28)\end{array}$ & $\begin{array}{l}9.35 \\
(1.89)\end{array}$ & $\begin{array}{r}39.33 \\
(5.83)\end{array}$ \\
\hline $\begin{array}{l}\text { Note: } \\
{ }^{\mathrm{a}} \text { The first val } \\
\text { deviations are } \\
{ }^{\mathrm{b}} \text { Maximum p } \\
{ }^{\mathrm{c}} \text { Average sco } \\
{ }^{\mathrm{d}} \text { Two franchi } \\
\text { too many mis }\end{array}$ & $\begin{array}{l}\text { the columns are } \\
\text { rentheses. } \\
\text { e score accordir } \\
\text { ording to the G } \\
\text { nd one franchis } \\
\text { nformation. }\end{array}$ & $\begin{array}{l}\text { the mean entrepr } \\
\text { g to the GET test. } \\
\text { T test. } \\
\text { r were excluded } \mathrm{f}\end{array}$ & $\begin{array}{l}\text { neurship sco } \\
\text { om the GET }\end{array}$ & $\begin{array}{l}\text { res for each gr } \\
\text { analysis as the }\end{array}$ & p, and the & dard \\
\hline
\end{tabular}

